\title{
Study The Population Fluctuation of The Red Palm Weevil Rhynchophorus ferrugineus in Two Different Egyptian Regions
}

Hamouda $^{2}$, A. A.; A.A. Darwish', S.M. Halawa ${ }^{1}$ and F.F. Abdallah ${ }^{2}$

1 - Fac. of Agriculture, Benha University, Moshtohr Branch

2- Plant Protection Research Institute, ARC, Dokki, Giza, Egypt

\begin{abstract}
The population fluctuation of the red palm weevil, $R$. ferrugineus was studied, using the aggregation pheromone traps, during 2016/2017 and 2017/2018 in two different regions of Egypt as follows:

a- Alexandria Governorate: The population of $R$. ferrugineus attracting to the trap number 1 , increased gradually from mid of July 2016 (7individuals) to reach its peak in mid of September (26individuals), and then decrease to reach the lowest level of abundance at middle of January 2017 (2insect only). Also, there was another peak of $R$. ferrugineus noticed during beginning of July 2017 (26insects). The attracting insects to the trap 2 had the same trend in the previously mentioned trap, as the highest population of the insects was noticed during the middle of September 2016 recording 32 insects, but the lowest population of collected insect was observed during the end of January 2017. The males in the tested traps were disappeared during the period from the end of January to the middle of February 2017.The highest number of attracted $R$. ferrugineusat Alexandria was recorded during $13 / 9 / 2017$ in the first trap (22insects), but the second trap had attracted the highest number of insects at the same investigation time as (30insects). The period of end of January 2018 to the middle of February was avoiding the appearance of insects in the first trap but in the second trap, the insects disappeared during the period of 3/1/2018 till 14/2/2018 for

b- El-Beihera region: The sampling date 9/10/2016 harbored the highest population of both males and females of $R$. ferrugineus in El- Behira in the first trap. In the second trap the highly abundance of weevil for the sampling date 11/4/2017 (38 insects). Also, the study showed that the number of females was higher than the males in most cases. The highest population was recorded during 9/10/2017 in the first trap (33individuals), but the date $11 / 4 / 2018$ showed the highest $R$. ferrugineus abundance in the second trap (34insects). The current study indicated that there were highly significant differences between the total number of males and the regions, but there was no any effect of seasons separately on this population in the trap 1. Also, the interaction between the regions and study seasons had no any effect on the male's populations. There were no any effects for regions and study seasons on the population of $R$. ferrugineus inside the trap number 2 . In trap 1, there were positive correlations between the effect of females and temperature on the population of the males. Also, the same correlations were observed for effect of males and temperatures on the population of female populations. However, the effect of relative humidity factor on the population of male and females was negative effect in both tested traps. The study indicated that El-Behira region harbored more $R$. ferrugineus than Alexandria during the two study seasons. The average insects were 4.615 and 3.653 insects in Alexandria and 6.5 and 5.57 in El-Behira, during the two seasons, respectively.
\end{abstract}

Key Word: Rhynchophorus ferrugineus, Fluctuation, Red Palm Weevil

\section{Introduction}

The date palm, Phoenix dactylifera (Palmae) is the most common and widely cultivated plant in the arid regions of the Middle East and North Africa where, in many areas, its fruit has provided the carbohydrate food of local people, (Jones 1995). Red palm weevil (RPW) $R$. ferrugineus (Olivier) (Coleoptera: Curculionidae) was first described in India as a serious pest of coconut palm (Lefroy, 1906) and later on it was reported on date palm (Buxton, 1918). During the last decade of the $20^{\text {th }}$ century $R$. ferrugineus was firstly recorded in date palm plantations in Egypt (Saleh and Gouhar, 1993). Red palm weevil was firstly discovered attacking palm in the Arabian peninsula especially United Emirates at 1986 and progressively spread to Gulf states and crossed the red sea into North Africa as the latest record since 1992 in Egypt. The related species is highly polyphagous with number of known hosts exceeding more than ten different palm species (Murphy and Briscoe, 1999). It is likely that the origin of this pest was South East of Asia, mainly in Pakistan, India, Burma, Bangladesh and Indonesia, as have been reported by International Institute of Entomology in London (Liver, 1969) and speeded later in many other countries where date palms are grown such as Iran and Arabian countries; (Iraq, Saudi Arabia, Emirates and recently in Egypt). The larval stages feed inside the trunk and frequently destroy the apical growth area, causing the death of the palm (Murphy and Briscoe, 1999). In 1995, three years after its first discovery in Egypt, an Egyptian Agricultural Official considered that the red palm weevil had been eradicated (Ferry 1996). Consequently, the recent strategy has focused on Integrated Pest Management programmes including sanitation, cultural, trapping, and chemical and biological control (Peter 1989; Gobinadhan et al. 
1990; Rajan and Nair 1997; Murphy and Briscoe 1999; Hanounik et al.2000; Abbas 2000). The aim of this work is study the seasonal abundance of $R$. ferrugineus in two regions during the two different seasons.

\section{Materials and methods}

This work was carried out from January 2015 to October 2019 in Alexandria Governorate (El-Ameiria region) and El-Beheira Governorate (Itay El-Barrood region), Egypt to study the population fluctuation of adults of (RPW) Rhynchophorus ferrugineus (Oliv.) by using Pheromone traps. Two pheromone traps were distributed in the investigated orchards (5feddan). Pheromone traps designed and applied according to (Hanounik et al., 2000), the pheromone trap consists of ten liter plastic container with four circular holes in the cover and six holes near the upper edge of side walls. Each trap contained dispenser of the $R$. ferrugineus male aggregation pheromone containing $700 \mathrm{mg}$ of the active ingredient (4Methyl-5-Nonanol (9 parts)+4- Methyl-5-onanon (1 part) (pheromone lure was Manufactured by Chim Tica international S.A. company, Costa Rica. Trade Name PO28Ferrolure+ 700mg lure, consists of a mixture of 4-methyl 5- nonanol and 4-methyl 5-nonanone (9:1part purity of both components, $95 \%$ release rate 3-10mg/day). Dispenser of the kairomone containing $45 \mathrm{ml}$ of the active ingredient Ethyl Acetate in gel, at $95 \%$ minimum purity, release rate $200-400 \mathrm{mg}$ /day colorant added (kairomone manufactured by Chim Tica international S.A. Company, Costa Rica. Trade Name PO80A weevil magent $45 \mathrm{~mL}$ lure). The prepared traps were placed under the shade of palm canopy to obtain a uniform and sustained release of the chemical (Oehlschlager et al., 2002). Traps maintenance was required during the experimental period. All traps were inspected every 15 days during the experimental period to register number of trapped weevils, clean traps, refresh the water and food baits and maintenance the traps during the experimental period. To provide better grip for the attracted weevils, jute cloth was stuck on the outer side of the bucket. The bottom of the bucket is filled with water and various nutritious attractants as baits (dates, sugar cane, and palm materials) to maintain high humidity level and to drown the weevils. A dispenser of the red palm weevil aggregation pheromone lure (4-metil-5nonanol a $90 \%(w / w)$ y de 4-metil-5-nonanone a $10 \%$ (w/w)) (Chema Tica International, San José, Costa Rica) are hung below the lid using a metal wire. Pheromone lure is replaced in each two months before running out. Pheromone-food baited traps were buried on the ground until the level of holes to facilitate entrance the weevils. The environmental conditions data (temperatures and relative humilities) were obtained from The Metrological Station in Giza. Each trap, according to El-Lakwah et al. (2011) contained the following materials:
1- $\quad 250 \mathrm{~g}$ of dates.

2- dispenser of the $R$. ferrugineus male aggregation pheromone (Pheromone lure was manufactured by Chim Tica international S.A. Company, Costa Rica. Trade Name PO28 Ferroluree+700mg lure, consists of a mixture of 4-methyl 5 - nonanol and 4- methyl 5nonanone (9:1part purity of both components $95 \%$ release rate 3-10 $\mathrm{mg} /$ day).

3- Dispenser of the kairomone containing $45 \mathrm{~mL}$ of the active ingredient ethyl acetate in gel, at $95 \%$ minimum purity, release rate $200-400 \mathrm{mg} /$ day colorant added (Kairomone manufactured by ChimTica inter. S.A. Company, Costa Rica. Trade Name PO80A weevil magnet $45 \mathrm{~mL}$ lure)

4- 5L of water. Traps were fabricated using a $10 \mathrm{~L}$ polypropylene bucket .The outer surface of the bucket was rough with plastic net (1-2 mm). Traps were without cover and buried in the ground down to the level of $15 \mathrm{~cm}$ to facilitate entrance of $R$. ferrugineus adults. Part-burying of the trap also prevented it from being over-turned by wind or animals or water of flooded irrigation. Each trap was 4 meter away from date palm trees (to avoid that any adult could miss the trap and lay eggs on the palmtree) in the shade to avoid evaporation. The water was always replenished every two weeks to keep sufficient moisture in each trap for avoid escaping of the adult and it help to kill the insects. Food bait (dates) was renewed every two weeks. Based on the dispensing rates, the pheromone and the kairomone were replaced every 2 months. Trapped weevils were collected, removed, counted, sexed and recorded every two weeks. Correlation coefficient and regression values were calculated

\section{Results and discussion}

\section{Population fluctuation of red palm weevil during} 2016/2017 and 2017/2018:

The population fluctuation of the red palm weevil, $R$. ferrugineus was studied, using the aggregation pheromone traps, during 2016/2017 and 2017/2018 in two different regions of Egypt as follows:

\section{I- During 2016/2017}

\section{A- Alexandria Governorate}

As shown in Table (1) The insect population of red palm weevil (males and females) attracting to the trap number 1, increased gradually from mid of July 2016 (7insects) to reach its peak in mid of September (26individuals), and then decrease to reach the lowest level of abundance at middle of January 2017 (2insect only). Also, the same obtained data indicated that there was another peak of red palm weevil was noticed during beginning of July 2017 (26 insects). On the other hand, the attracting insects to the trap number 2 had the same trend in the previously mentioned trap, as the highest population of the insects was noticed during the middle of September 2016 recording 32 individuals, but the lowest population of collected insect was observed during the end of January 2017 (2insects). The males of collected insects to the two 
tested traps were disappeared during the period from the begining of January to the middle of February 2017. Data obtained proved that the reliable number of captured red palm weevil occurred during warm periods which extended from March until November, while, there was scarcely distributed individuals during winter months.

Table 1. The number of attracting insects (RPW) to the pheromone traps in Alexandria Governorate during (2016/2017) season

\begin{tabular}{|c|c|c|c|c|c|c|c|c|}
\hline \multirow{2}{*}{$\begin{array}{c}\text { Sampling } \\
\text { dates }\end{array}$} & \multicolumn{3}{|c|}{ Trap No. 1} & \multicolumn{3}{|c|}{ Trap No. 2} & \multirow[t]{2}{*}{ Tem. ${ }^{\circ} \mathrm{C}$} & \multirow[t]{2}{*}{$\mathrm{RH} \%$} \\
\hline & $\begin{array}{l}\text { No. of } \\
\text { males }\end{array}$ & $\begin{array}{l}\text { No. of } \\
\text { females }\end{array}$ & $\begin{array}{l}\text { Total no. } \\
\text { of insect }\end{array}$ & $\begin{array}{l}\text { No. of } \\
\text { males }\end{array}$ & $\begin{array}{l}\text { No. of } \\
\text { females }\end{array}$ & $\begin{array}{l}\text { Total no. } \\
\text { of insect }\end{array}$ & & \\
\hline July 19/2016 & 3 & 4 & 7 & 4 & 5 & 9 & 32.0 & 40.5 \\
\hline August 2 & 4 & 11 & 15 & 7 & 8 & 15 & 30.5 & 39.7 \\
\hline 16 & 4 & 17 & 21 & 9 & 9 & 18 & 28 & 37.8 \\
\hline 30 & 9 & 15 & 24 & 7 & 15 & 22 & 26.5 & 40.6 \\
\hline September 13 & 1 & 11 & 26 & 13 & 19 & 32 & 24.8 & 40.1 \\
\hline 27 & 4 & 6 & 10 & 11 & 12 & 23 & 23.1 & 40.0 \\
\hline October 11 & 7 & 11 & 18 & 2 & 5 & 7 & 22.5 & 40.8 \\
\hline 25 & 1 & 11 & 21 & 2 & 6 & 8 & 20.5 & 44.2 \\
\hline November 8 & 3 & 8 & 11 & 2 & 6 & 8 & 18.5 & 50.6 \\
\hline 22 & 5 & 6 & 11 & 2 & 4 & 6 & 16.4 & 49.1 \\
\hline December 6 & 4 & 5 & 9 & 4 & 5 & 9 & 15.4 & 48.6 \\
\hline 20 & 2 & 2 & 4 & 5 & 6 & 11 & 14.8 & 48.3 \\
\hline January 3/2017 & 2 & 2 & 4 & 0 & 3 & 3 & 15.2 & 47.9 \\
\hline 17 & 2 & 0 & 2 & 0 & 5 & 5 & 15.2 & 45.0 \\
\hline 31 & 0 & 4 & 4 & 0 & 2 & 2 & 17.6 & 44.1 \\
\hline February 14 & 0 & 3 & 3 & 0 & 6 & 6 & 18.5 & 42.5 \\
\hline 28 & 3 & 5 & 8 & 5 & 4 & 9 & 19.2 & 38.5 \\
\hline March 14 & 3 & 4 & 7 & 6 & 3 & 9 & 19.4 & 34.0 \\
\hline 28 & 4 & 5 & 9 & 13 & 16 & 29 & 19.0 & 33.0 \\
\hline April 11 & 0 & 6 & 6 & 9 & 8 & 17 & 21.4 & 29.8 \\
\hline 25 & 3 & 10 & 13 & 18 & 19 & 37 & 24.3 & 29.7 \\
\hline May 9 & 2 & 0 & 2 & 5 & 4 & 9 & 27.1 & 33.0 \\
\hline 23 & 7 & 5 & 12 & 6 & 10 & 16 & 28.5 & 32.0 \\
\hline June 6 & 5 & 3 & 8 & 5 & 7 & 12 & 29.1 & 30.8 \\
\hline 20 & 5 & 15 & 20 & 8 & 13 & 21 & 30.5 & 31.0 \\
\hline July 4 & 10 & 16 & 26 & 4 & 4 & 8 & 30.2 & 30.7 \\
\hline Total & 112 & 184 & 296 & 147 & 204 & 351 & - & - \\
\hline Average & 4.3 & 7.07 & 11.38 & 5.6 & 7.8 & 13.5 & - & - \\
\hline
\end{tabular}

b-) El-Beihera region: As shown in Table (2), the most attracted red palm weevil was observed in the second trap thane the first one. The obtained data showed that the sampling date $9 / 10 / 2016$ harbored the highest population of both males and females in the collected insects in El- Behira Governorate in the first trap. However, in the second trap the highly abundance of red palm weevil for the sampling date 11/4/2017 (38 attracted males and females). Also, the current study showed that the number of collected females was higher than the males in most casesand in the two tested trap. Table (2) also showed the population fluctuation of males and females separately.

II-) The second season 2017/2018: In the second season (2017/2018), seasonal prevalence of $R$. ferrugineus population had approximately similar trend of abundance as in the first year (2016/2017), but differed in the collected insect numbers in the two tested regions (Tables 3 and 4 ).
II-a) Alexandria region: The highest number of attracted red palm weevil at Alexandria region was recorded during 13/9/2017 in the first trap (22 insects) for both males and females, but the second trap had attracted the highest number of insects at the same investigation time was 30 insects (males and females), Table (3). The period of end of January 2018 to the middle of February was avoid the appearance of males and females in the first trap but in the second trap, the insects disappeared during the period of $3 / 1 / 2018$ till 14/2/2018 for males.

II- b-) El-Beihera region: As shown in Table (4) there were three different population peaks in the first trap, the first one recorded during the end of July 2017 (28 individuals), the second one observed as 33 insects during $9 / 10 / 2017$, while the third peak was occurred during 21/6/2018 in El-Beheira (28 individuals). However, in the second trap, there were two peaks of red palm weevil in El-Behira, the first one during $11 / 9 / 2017$ (26 insects), the second peak noticed during $11 / 4 / 2018$ with 34 insects, as, the last peak was 
recorded during 23/5/2018 in this trap and region (21 insects). Generally, the population fluctuation of the total number of red palm weevil in El-Beihera was obviously higher than that obtained in Alexandria

Effect of environmental conditions on the population of the red palm weevil: Tables (1-4) explained the population dynamics of the red palm weevil in two different regions at two different seasons. The simple correlation value (r's) helping in detecting any apparent relationship between the population of the red palm weevil, $R$. ferrugineus and each of the tested factors. The regression value (b) indicated the average rate of changes in the activity of the insect due to the unit change in any of the tested factors.

Trap number 1: The tabulated data in Table (5) showed the effect of both regions and study season on the population of the red palm weevil in the two tested regions (Alexandria and El-Behira). The data indicated that there were highly significant differences between the total number of collected males and the different regions, but there was no any effect of seasons separately on this population in the trap number 1. Also, the interaction between the regions and study seasons had no any effect on the male's populations. The analysis of data showed that LSD at $0.05=1.3518$. The same data also showed that the same trend in the population of the $R$. ferrugineus females and also the total number of collected insects, as in male. The statistical analysis of obtained data showed that LSD at $0.05=2.0074$ and 3.2209, respectively.

Trap umber 2: The current study showed that there were no any effects for regions and study seasons on the population of the red palm weevil, $R$. ferrugineus inside the trap number 2 . The statistical analysis of obtained data indicated that LSD at 0.05 level = 1.6627, 1.8099 and 3.359 for effect of regions, study season and interaction between regions and seasons, respectively, Table (5).

Table 2. The number of attracting insects (RPW) to the pheromone traps in El-Behira during (2016/2017) season

\begin{tabular}{|c|c|c|c|c|c|c|c|c|}
\hline \multirow{2}{*}{$\begin{array}{c}\text { Sampling } \\
\text { dates }\end{array}$} & \multicolumn{3}{|c|}{ Trap No. 1} & \multicolumn{3}{|c|}{ Trap No. 2} & \multirow{2}{*}{$\begin{array}{l}\text { Tem. } \\
{ }^{\circ} \mathrm{C}\end{array}$} & \multirow[t]{2}{*}{ RH\% } \\
\hline & $\begin{array}{l}\text { No. of } \\
\text { males }\end{array}$ & $\begin{array}{l}\text { No. of } \\
\text { females }\end{array}$ & $\begin{array}{l}\text { Total no. } \\
\text { of insect }\end{array}$ & $\begin{array}{l}\text { No. of } \\
\text { males }\end{array}$ & $\begin{array}{l}\text { No. of } \\
\text { females }\end{array}$ & $\begin{array}{l}\text { Total no. } \\
\text { of insect }\end{array}$ & & \\
\hline July 3/2016 & 5 & 6 & 11 & 6 & 7 & 13 & 32.6 & 42.5 \\
\hline 17 & 11 & 14 & 25 & 9 & 11 & 20 & 31.3 & 41.0 \\
\hline 31 & 11 & 19 & 30 & 9 & 11 & 20 & 28.5 & 37.9 \\
\hline August 14 & 13 & 15 & 28 & 7 & 9 & 16 & 26.9 & 42.0 \\
\hline 28 & 11 & 15 & 26 & 12 & 14 & 26 & 24.7 & 40.9 \\
\hline September 11 & 8 & 8 & 16 & 13 & 15 & 28 & 23.9 & 40.8 \\
\hline 25 & 8 & 13 & 21 & 5 & 8 & 13 & 22.7 & 42.0 \\
\hline October 9 & 12 & 21 & 33 & 5 & 9 & 14 & 21.0 & 44.8 \\
\hline 23 & 5 & 10 & 15 & 2 & 5 & 7 & 18.8 & 53.6 \\
\hline November 6 & 6 & 9 & 15 & 3 & 5 & 8 & 17.2 & 50.8 \\
\hline 20 & 6 & 8 & 14 & 5 & 7 & 12 & 16.4 & 52.1 \\
\hline December 4 & 5 & 5 & 10 & 4 & 3 & 7 & 14.4 & 49.7 \\
\hline 18 & 4 & 5 & 9 & 0 & 3 & 3 & 15.9 & 49.0 \\
\hline January $1 / 2017$ & 2 & 0 & 2 & 0 & 2 & 2 & 16.3 & 45.8 \\
\hline 15 & 0 & 0 & 0 & 0 & 1 & 1 & 18.5 & 44.8 \\
\hline 29 & 0 & 0 & 0 & 0 & 1 & 1 & 19.2 & 43.5 \\
\hline February 12 & 4 & 7 & 11 & 8 & 10 & 18 & 19.6 & 39.6 \\
\hline 26 & 7 & 8 & 15 & 9 & 11 & 20 & 20.4 & 39.8 \\
\hline March 14 & 7 & 10 & 17 & 11 & 13 & 24 & 21.0 & 33.8 \\
\hline 28 & 0 & 2 & 2 & 9 & 12 & 21 & 21.7 & 32.0 \\
\hline April 11 & 4 & 8 & 12 & 18 & 20 & 38 & 24.8 & 32.8 \\
\hline 25 & 3 & 6 & 9 & 8 & 10 & 18 & 27.8 & 33.9 \\
\hline May 9 & 7 & 17 & 24 & 7 & 9 & 16 & 29.5 & 37.6 \\
\hline 23 & 8 & 15 & 23 & 12 & 12 & 24 & 29.4 & 34.9 \\
\hline June 7 & 7 & 18 & 25 & 8 & 6 & 14 & 31.3 & 36.8 \\
\hline 21 & 15 & 17 & 32 & 6 & 8 & 14 & 30.4 & 34.6 \\
\hline Total & 169 & 256 & 425 & 176 & 220 & 398 & - & - \\
\hline Average & 6.5 & 9.8 & 16.3 & 6.7 & 8.5 & 15.3 & - & - \\
\hline
\end{tabular}


Table 3. The number of attracting insects (RPW) to the pheromone traps in Alexandria during (2017/2018) seasons

\begin{tabular}{|c|c|c|c|c|c|c|c|c|}
\hline \multirow{2}{*}{$\begin{array}{c}\text { Sampling } \\
\text { dates }\end{array}$} & \multicolumn{3}{|c|}{ Trap No. 1} & \multicolumn{3}{|c|}{ Trap No. 2} & \multirow{2}{*}{$\begin{array}{l}\text { Tem. } \\
{ }^{\circ} \mathrm{C}\end{array}$} & \multirow[t]{2}{*}{ RH\% } \\
\hline & $\begin{array}{l}\text { No. of } \\
\text { males }\end{array}$ & $\begin{array}{l}\text { No. of } \\
\text { females }\end{array}$ & $\begin{array}{l}\text { Total no. of } \\
\text { insect }\end{array}$ & $\begin{array}{ll}\text { No. } & \text { of } \\
\text { males } & \\
\end{array}$ & $\begin{array}{l}\text { No. of } \\
\text { females }\end{array}$ & $\begin{array}{l}\text { Total no. } \\
\text { of insect }\end{array}$ & & \\
\hline July 19/2017 & 2 & 5 & 7 & 4 & 4 & 8 & 32.6 & 40.9 \\
\hline August 2 & 4 & 9 & 13 & 6 & 7 & 13 & 30.7 & 40.2 \\
\hline 16 & 3 & 13 & 16 & 8 & 8 & 16 & 28.8 & 37.9 \\
\hline 30 & 7 & 12 & 19 & 7 & 15 & 22 & 27.1 & 41.4 \\
\hline September 13 & 12 & 10 & 22 & 11 & 19 & 30 & 25.3 & 40.4 \\
\hline 27 & 4 & 5 & 9 & 10 & 11 & 21 & 23.8 & 40.2 \\
\hline October 11 & 8 & 9 & 17 & 2 & 4 & 6 & 23.5 & 40.9 \\
\hline 25 & 9 & 7 & 16 & 1 & 6 & 7 & 21.4 & 45.1 \\
\hline November 8 & 3 & 7 & 10 & 1 & 6 & 7 & 18.9 & 50.9 \\
\hline 22 & 3 & 5 & 8 & 2 & 4 & 6 & 17.3 & 53.2 \\
\hline December 6 & 3 & 4 & 7 & 3 & 4 & 7 & 15.4 & 49.8 \\
\hline 20 & 2 & 2 & 4 & 4 & 4 & 8 & 14.9 & 48.9 \\
\hline January 3/2018 & 2 & 2 & 4 & 0 & 3 & 3 & 16.1 & 48.7 \\
\hline 17 & 1 & 0 & 1 & 0 & 3 & 3 & 16.2 & 45.8 \\
\hline 31 & 0 & 3 & 3 & 0 & 2 & 2 & 17.9 & 44.9 \\
\hline February 14 & 0 & 3 & 3 & 0 & 5 & 5 & 19.5 & 43.6 \\
\hline 28 & 2 & 3 & 5 & 3 & 5 & 8 & 20.3 & 39.4 \\
\hline March 14 & 2 & 4 & 6 & 5 & 3 & 8 & 20.8 & 34.9 \\
\hline 28 & 3 & 5 & 8 & 11 & 13 & 24 & 19.8 & 33.8 \\
\hline April 11 & 0 & 5 & 5 & 7 & 5 & 12 & 21.9 & 30.2 \\
\hline 25 & 2 & 8 & 10 & 14 & 16 & 30 & 25.3 & 31.0 \\
\hline May 9 & 2 & 0 & 2 & 6 & 3 & 9 & 28.4 & 33.9 \\
\hline 23 & 6 & 5 & 11 & 4 & 11 & 15 & 28.9 & 33.0 \\
\hline June 6 & 4 & 3 & 7 & 4 & 8 & 12 & 30.3 & 32.8 \\
\hline 20 & 4 & 11 & 15 & 7 & 11 & 18 & 31.5 & 32.1 \\
\hline July 4 & 7 & 14 & 21 & 3 & 3 & 6 & 30.9 & 30.9 \\
\hline Total & 95 & 154 & 249 & 123 & 183 & 306 & - & - \\
\hline Average & 3.6 & 5.9 & 9.5 & 4.7 & 7.03 & 11.7 & - & - \\
\hline
\end{tabular}

Table 4. The number of attracting insects (RPW) to the pheromone traps in El-Behira during (2017/2018) season

\begin{tabular}{|c|c|c|c|c|c|c|c|c|}
\hline \multirow{2}{*}{$\begin{array}{c}\text { Sampling } \\
\text { dates }\end{array}$} & \multicolumn{3}{|c|}{ Trap No. 1} & \multicolumn{3}{|c|}{ Trap No. 2} & \multirow[t]{2}{*}{ Tem. ${ }^{\circ} \mathrm{C}$} & \multirow[t]{2}{*}{ RH\% } \\
\hline & $\begin{array}{l}\text { No. of } \\
\text { males }\end{array}$ & $\begin{array}{l}\text { No. of } \\
\text { females }\end{array}$ & $\begin{array}{l}\text { Total no. of } \\
\text { insect }\end{array}$ & $\begin{array}{l}\text { No. of } \\
\text { males }\end{array}$ & $\begin{array}{l}\text { No. of } \\
\text { females }\end{array}$ & $\begin{array}{l}\text { Total no. of } \\
\text { insect }\end{array}$ & & \\
\hline July $3 / \mathbf{2 0 1 7}$ & 6 & 6 & 12 & 6 & 5 & 11 & 33.4 & 44.0 \\
\hline $17^{\circ}$ & 8 & 12 & 20 & 8 & 10 & 18 & 31.9 & 44.1 \\
\hline 31 & 10 & 18 & 28 & 9 & 11 & 20 & 28.7 & 39.4 \\
\hline August 14 & 12 & 14 & 26 & 6 & 8 & 14 & 28.1 & 43.2 \\
\hline 28 & 10 & 14 & 24 & 11 & 13 & 24 & 25.6 & 42.9 \\
\hline September 11 & 6 & 8 & 14 & 12 & 14 & 26 & 24.4 & 41.8 \\
\hline 25 & 6 & 12 & 18 & 5 & 8 & 13 & 23.4 & 42.9 \\
\hline October 9 & 9 & 19 & 18 & 4 & 8 & 12 & 21.9 & 45.4 \\
\hline 23 & 5 & 8 & 13 & 1 & 4 & 5 & 19.5 & 56.3 \\
\hline November 6 & 5 & 9 & 14 & 2 & 5 & 7 & 18.4 & 53.2 \\
\hline 20 & 5 & 9 & 14 & 6 & 7 & 13 & 17.6 & 53.5 \\
\hline December 4 & 4 & 5 & 9 & 3 & 2 & 5 & 15.2 & 49.8 \\
\hline 18 & 4 & 5 & 9 & 0 & 1 & 1 & 16.3 & 51.1 \\
\hline January $1 / 2018$ & 2 & 0 & 2 & 0 & 2 & 2 & 17.4 & 52.1 \\
\hline 15 & 0 & 0 & 0 & 0 & 1 & 1 & 19.5 & 46.2 \\
\hline 29 & 0 & 0 & 0 & 0 & 0 & 0 & 19.8 & 45.5 \\
\hline February 12 & 3 & 6 & 9 & 6 & 12 & 18 & 19.5 & 40.1 \\
\hline 26 & 6 & 7 & 13 & 8 & 12 & 20 & 25.1 & 40.6 \\
\hline March 14 & 6 & 9 & 15 & 10 & 10 & 20 & 22.2 & 35.1 \\
\hline 28 & 0 & 2 & 2 & 9 & 10 & 19 & 22.9 & 32.9 \\
\hline April 11 & 3 & 7 & 10 & 16 & 18 & 34 & 25.4 & 33.7 \\
\hline 25 & 3 & 7 & 10 & 6 & 11 & 17 & 28.7 & 34.2 \\
\hline May 9 & 6 & 15 & 21 & 6 & 7 & 13 & 30.2 & 39.1 \\
\hline 23 & 8 & 12 & 20 & 11 & 10 & 21 & 30.7 & 35.1 \\
\hline June 7 & 5 & 17 & 22 & 8 & 5 & 13 & 33.0 & 37.1 \\
\hline 21 & 13 & 15 & 28 & 5 & 7 & 12 & 30.9 & 36.0 \\
\hline Total & 145 & 236 & 381 & 158 & 201 & 359 & - & - \\
\hline Average & 5.5 & 9.07 & 14.6 & 6.07 & 7.7 & 13.8 & - & - \\
\hline
\end{tabular}


Table 5. Effect of both region and study seasons on the population fluctuation of the (RPW), R. ferrugineus

\begin{tabular}{|c|c|c|c|c|}
\hline variable & source & F. & P. & LSD at 0.05 \\
\hline Male individuals & region & 8.4501 & $0.0045^{* *}$ & \multirow[t]{3}{*}{1.3518} \\
\hline \multirow[t]{2}{*}{ in trap No. 1} & Season & 1.6129 & $0.2070^{\mathrm{ns}}$ & \\
\hline & Int. region*season & 0.0072 & 0.9327 & \\
\hline Female & region & 8.4563 & $0.00468 * *$ & \multirow[t]{3}{*}{2.0074} \\
\hline individuals in trap & Season & 0.9395 & $0.3347^{\mathrm{ns}}$ & \\
\hline No. 1 & Int. region*season & 0.0437 & $0.8348^{\mathrm{ns}}$ & \\
\hline Total insects in & region & 10.6113 & $0.0015 * *$ & \multirow[t]{3}{*}{3.2209} \\
\hline \multirow[t]{2}{*}{ trap No. 1} & Season & 0.8319 & $0.3639^{\mathrm{ns}}$ & \\
\hline & Int. region*season & 0.10228 & $0.7498^{\mathrm{ns}}$ & \\
\hline Male individuals & region & 0.7405 & $0.33916^{\mathrm{ns}}$ & \multirow[t]{3}{*}{1.6627} \\
\hline \multirow[t]{2}{*}{ in trap No. 2} & Season & 2.4707 & $0.1191^{\mathrm{ns}}$ & \\
\hline & Int. region*season & 0.5562 & $0.4578^{\mathrm{ns}}$ & \\
\hline Female & region & 0.5443 & $0.4624^{\mathrm{ns}}$ & \multirow[t]{3}{*}{1.8099} \\
\hline individuals in trap & Season & 0.7469 & $0.3895^{\mathrm{ns}}$ & \\
\hline No. 2 & Int. region*season & 4.4434 & $0.9832^{\mathrm{ns}}$ & \\
\hline Total insects in & region & 1.2902 & $0.2587^{\mathrm{ns}}$ & \multirow[t]{3}{*}{3.359} \\
\hline \multirow[t]{2}{*}{ trap No. 2} & Season & 0.9103 & $0.3423^{\mathrm{ns}}$ & \\
\hline & Int. region*season & 0.0046 & $0.9458^{\mathrm{ns}}$ & \\
\hline
\end{tabular}

LSD $=$ Least significant differences

* Significant ** high significant ns not significant

In case of trap no. 1, as shown in Table (6), there were positive correlations between the effect of female individuals and temperature factors on the population of the male individuals. Also, the same correlations were observed for effect of males and temperatures factors on the population of female populations. However, the effect of relative humidity factors on the population of male and female's indiduals was negative effect in both tested traps. The data in Table (7) showed that the mean number of males and females of $\mathrm{R}$. ferrugineus in both tested traps. The average number of males was 5.048 and 6.063 insect through trap 1 and 2, changed to recorded 7.99 and 7.779 females, $R$. ferrugineus.Also, the average total number of males and females recorded 13.22 and 13.59 during the two study seasons in the tested locations, respectively. However, the current study indicated that El-Behira harboured more attracted red palm weevil, $R$. ferrugineus than Alexandria during the two study seasons 2016/2017 and 2017/2018, Table (8). The average attracted insects were 4.615 and 3.653 insects for Alexandria and 6.5 and 5.57 individuals for ElBehira, during the two seasons, respectively.

The use of pheromones in monitoring and controlling RPW populations has become an important effective tool (El-Ezaby et al., 1998; Faleiro, 2005). The obtained results are in disagreement with the findings of Abdallah and Al-Khatri (2005), who observed that RPW adults emerging continually throughout the year Also, these data insure the data obtained by Qin $\boldsymbol{e t}$ al., (2004) who found that, the population monitoring of red palm weevil occurred in four peaks a year in the area of Wenchang, Hainan
Province. The adult population abundance of RPW according to the previously mentioned data is not exactly existed all over the year in two years of study. These results in general disagree with the findings of El-Sebay (2003) andEL-Lakwah et al. (2011). Average of $R$. ferrugineus adults captured by aggregation pheromone was different during the two years of study. These results in general agree with the findings of Muralidharanet al. (2000) who found that in India the highest population density of the red palm weevil was observed in May (29.6/trap), March (16/trap) and December (4.6/trap). Abbas (2000 and Abbas et al, 2005) in Egypt estimated four overlapping generations of red palm weevil adults per year.

El Ezaby et al. (1998) reported maximum catches in March and April. The study conducted by Abbas $\boldsymbol{e t}$ al. (2005) indicated that the insect population of red palm weevil increased gradually from January to reach its peak in March, April, or May. An evaluation of the performance of the pheromone traps showed that they could capture 4.4 to $20.7 \%$ of the resident populations of $R$. ferrugineus in the three different date palm plantations. No significant differences could be found in rates of capture between males and females. ElSebaey (2003) indicated that $R$. ferrugineus had two main active seasons annually. The first adult brood was observed in April and the second one was in November. Female density was higher than male density and it constituted $52.8-57.35 \%$ of the total population in the field. In addition, Faleiro (2005) found that the weevil captures were female dominated and for every male trapped two female weevils were captured. 
Table 6. The correlation between the different factors on the population of $R$. ferrugineus

\begin{tabular}{|c|c|c|c|c|c|}
\hline Trap No. & (x) variable & (Y) variable & Correlation & Sloop (b) & (Y) Int. (a) \\
\hline \multirow[t]{6}{*}{1} & Male & Female & 0.7675 & 1.136 & 3.2535 \\
\hline & & Tem. & 0.399 & 0.654 & 19.92 \\
\hline & & RH & -0.0557 & -0.103 & 41.49 \\
\hline & Female & Male & 0.7675 & 0.5183 & 0.9059 \\
\hline & & Tem. & 0.5133 & 0.5677 & 18.687 \\
\hline & & RH & -0.1782 & -0.2227 & 42.7525 \\
\hline \multirow[t]{6}{*}{2} & Male & Female & 0.88319 & 0.9499 & 0.20199 \\
\hline & & Tem. & 0.40266 & 0.5522 & 19.875 \\
\hline & & RH & -0.5958 & -0.9234 & 46.57 \\
\hline & Female & Male & 0.8832 & 0.8212 & -0.3253 \\
\hline & & Tem. & 0.3595 & 0.4584 & 19.657 \\
\hline & & RH & -0.4721 & -0.6802 & 46.2649 \\
\hline
\end{tabular}

Table 7. The average means of different individuals of $R$. ferrugineusin the tested traps

\begin{tabular}{cllccc}
\hline Trap No. & Variable & Mean + SD & Minimum & Maximum \\
\hline \multirow{2}{*}{1} & Males & $5.048 \pm 3.6$ & 0 & 15 \\
& Females & $7.99 \pm 5.3$ & 0 & 21 \\
& Total insects & $13.22 \pm 8.6$ & 0 & 33 \\
& Males & $6.063 \pm 4.3$ & 0 & 19 \\
& Females & $7.779 \pm 4.6$ & 0 & 20 \\
& Total insects & $13.59 \pm 8.6$ & 0 & 38 \\
\hline
\end{tabular}

$\mathrm{SD}=$ standard deviation

Table 8. The average number of attracted (RPW), R. ferrugineusto traps in Alexandria and El-Behira Governorates during 2015/2016 and 2016/2017 seasons.

\begin{tabular}{clcccc}
\hline Season & Region & Mean No. of insects & SD \pm & Minimum & Maximum \\
\hline \multirow{2}{2}{$2016 / 2017$} & Alexandria & 4.615 & 3.47 & 0 & 15 \\
& El-Behira & 6.5 & 3.99 & 0 & 15 \\
& Alexandria & 3.653 & 2.925 & 0 & 12 \\
& El-Behira & 5.57 & 3.419 & 0 & 13 \\
\hline
\end{tabular}

\section{References}

Abbas, M. K. (2000). Studies on the red palm weevil, M. Sc. Thesis, Fac. of Agric., Zagazig University.

Abbas, M.S.; Hanounik, S. B. ; Shahdad, A. S. and AI-Bagham, S. A. (2005). Aggregation pheromone traps, a major component of IPM strategy for the red palm weevil, Rhynchophorus ferrugineus in date palms (Coleoptera: Curculionidae). Journal of Pest Science, 2:69-73.

Abdallah F. F. and Al-Khatri, S.A. (2005): The effect of pheromone, kairomone and food bait on attracting adults of red palm weevil, Rhynchophorus ferrugienus in the Sultanate of Oman in date palm plantations. 3rd int. Conf., Plant Protection Research Institute, Dokki, Egypt, 26-29 November, 2005. 1-6

Buxton, P.A. (1918). Report on the failure of date crops in Mesopotamia in 1918. Agricultural Directorate, M.F.F. Bassarah, Ball. No. 6

El Ezaby, F.; Khalifa, O. and El Assal, A. (1998). Integrated pest management for the control of red palm weevil Rhychophorus ferrugineus Oliv. in the United Arab Emirates, Eastern Region, Al Ain. 1st Con. on Date Palms. Al-Ain, UAE

EL-Lakwa, F.A.; EL- Banna, A. A.; EL-Hosay, R. and EL-Shafi, W.K.M. (2011). Population dynamics of the red palm weevil Rhynchophorus ferruginus (Oliv.) on date palm plantations in 6thOctober Governorate. Egypt. J. Agric. Res., 89 (3): 1105- 1118 .

El-Sebaey, Y. (2003). Ecological studies on the red palm weevil, Rhynchophorusferrugineus Oliv. (Coleoptera: Curculionidae) in Egypt. Egypt. J. Agric. Res., 81 (2): 523-529.

Faleiro J.R. (2005). Pheromone technology for the management of red palm weevil Rhynchophorus ferrugineus (Olivier) (Coleoptera: Rhynchophoridae). A key pest of coconut, Technical Bulletin No.4, ICAR Research Complex for Goa.40pp.

Ferry, M. (1996). La crise du secteurphoenicicoledans les pays méditerranéennes. Quelles recherché pour y répondre?. In: Ferry, M. \& Greiner, D. (Eds) Proceedings of the plenary sessions of the Elche International Workshop on Date Cultivation in Oasis Agriculture of Mediterranean Countries. Elche, Spain 25-27 April 1995. Options méditerranéennes 28:129-156

Gobinadhan P.B., Mohandas N. and Nair, K.P.V. (1990). Cytoplasmic polyhedrosis virus infecting red palm weevil in coconut. Curr Sci 59:577-580.

Hanounik, S. B., Hegazy G., Abbas M.S.T., Salem M., Saleh M.M.E., Mansour M.I., Al-Bagham 
S., Abuzuhaira R., Awash S.and Shaambia A. (2000). Biological control of Rhynchophorus ferrugineus as a major component of IPM. Proc. $1 \mathrm{st}$ Workshop on Control of date palm red weevil. 22-25 November 2000, AI-Ehsaa, Saudi Arabia pp 125-150.

Jones , C . R. (1995).Insect notes from the Philippines. Philippines Adri. Rev., 6: 246 - 250.

Lefroy, H.M. (1906). The more important insects injurious to Indian Agriculture, Govt. Press, Calcutta, India.

Liver, R.J.A. (1969). Pests of the coconut palm. FAO Rept., Rome, p. 113-117.

Muralidharan, C.M.; Sodagar, N.N. and Vaghasia, U.R. (2000). Survey, distribution, extent of damage, field behavior and biology of the red palm weevil, Rhynchophorusferrugineus (Oliv.) on date groves of Kachchh Gujarat). 20 (1): 35-46.

Murphy S.T., and Briscoe, B. R. (1999). The red palm weevil as an alien invasive: biology and prospects for biological control as a component of IPM. Biocontrol News and Information 20(1):3546.

Oehlschlager, A. C.; Pierco, H..D.; Morgan, J. R. B.; Wimalaratne, P.D.C.; Slosser, K.N.; King,
G.S.; Perez, P.; Gries, R,; Gries, G,; Borden, J.H.; Jiron, L.F.; Chinchilla, C.M. and Mexzon, R.G. (2002). Chirality and field testing of Rhynchophorus, the aggregation pheromone of the American palm weevil, Naturwissenschaften, 79:134-135.

Peter, C. (1989). A note on the mites associated with the red palm weevil, Rhynchophorus ferrugineus in Tami Nadu. J. Insect Sci 2:160-161

Qin, W.; Weiquan Ma; Zilong Wu; DuoyangCai; Xizhou Wang ;Yongzhuang Z. and Chaowen, H.H. (2004). Trapping of Red Palm weevil with several attractants and monitoring of its population in the field. Chinese Journal of Tropical Crops. , 2004-02.

Rajan P, and Nair C.P.R. (1997). Red palm weevilthe tissue borer of coconut palm. Indian Coconut J. Cochin 27(12):2-3.

Saleh, M.R.A. and Gouhar, K.A.(1993). Red palm weevil attacking date palm trees in limited areas of Egypt at the present time and how can be eradicated from these areas. Report of Plant Protection Department, Fac. of Agric. Zagazig Univ., pp. 20.

\section{دراسة التذبذب العددى لسوسة النخيل الحمراءRhynchophorus ferrugineus فى موقعين مختلفين من مصر

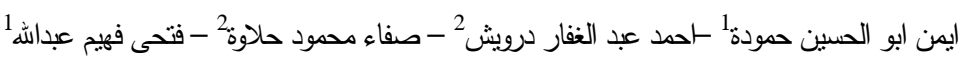

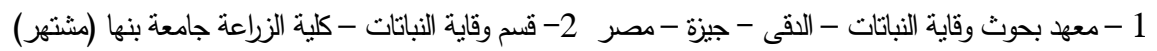

\footnotetext{
اجريت هذه الدراسة خلا موسمى 2017/2016 و 2018/2017 فى محافظتى الاسكندرية (منطقة النوبارية) والبحيرة (منطقى ايتاى البارود) لدراسة التذبذب العددى لحشرة سوسة النخيل الحمراء R. ferrugineus وتاثير العوامل الجوية (درجات الحرارة والرطوبة النسبية) باستخدام اثثين من المصائد الفرمونية على هذا التعداد.وقد اظهرت النتائج وجود الحشرة طوال العام بوجه عام وان الحشرة ظهر لها اكثر من قمة للتعداد.كماتثير



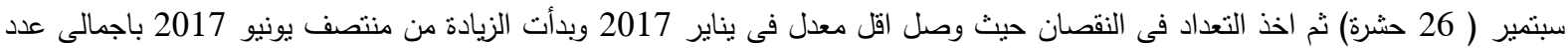
26 حشرة وظهر اعلى تعداد فى المصيدة الثانية فى سبتمبر 2616 مسجلة 32 حشرة كما كان اقل تعداد بنهاية يناير 2017 مع مع ملاحظة اختفاء الذكور فى المصيدة من نهاية يناير حتى منتصف فبراير 2017 وفى الموسم الثانى كان اعلى تعداد للحشرة فى سبتمبر 2017 حيث وصل الى 25


سجلت 30 حشرة وتلاش تماما تعداد الحشرات فى الفترة من نهاية يناير حتى منتصف فبراير 2018 فى المصبدة الثانية. كما نثير النتائج ان المصيدة الاولى بمحافظة البحيرة قد جذبت عدد اكبر من الحشرات بتعداد 38 حشرة فى 9 اكتوبر 2016 ثم تلاد ذلاد ذلك تعداد اعلى فى ابريل مسجلة ( 38حشرة)كما ان نسبة الاناث كانت اعلى من الذكور وفى الموسم الثانى وجدقمة فى اكتوبر 2017 ( 33 حشرة) ثم بدأ هذا التعداد فى الإنخفاض فئرة

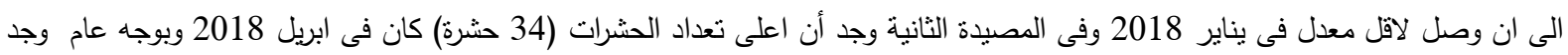

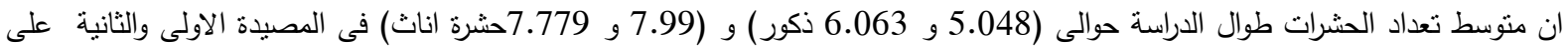

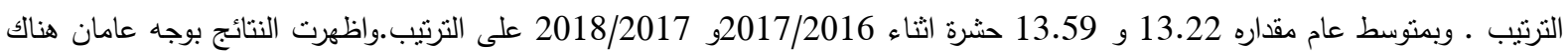
تاثيرات مختلفة لمتوسط درجات الحرارة والرطوبة النسبية على تعداد الحشرة فى المنطقتين خلال موسمى الدراسة. ومن نتائج الدراسة وجد انه لا يوجد تاثير لعامل المكان والزمان على تعداد حشرة سوسة النخيل الحمراء داخل المصيدة 2 اما فى المصيدة 1 فكان هناك ارتباط ايجابى بين تاثير الافراد الاناث ودرجات الحرارة على تعداد الافراد الذكور . ايضا نفس الارتباط لوحظ عند ناثثر الافراد الذكور ودرجات الحرارة على تعداد الافراد الاناث.ولقد دلت الدراسة ان متوسط عدد الحشرات طول العام كان فى محافظة البحيرة اعلى من محافظة الاسكندرية حيث كان المتوسط حشرة فى الاسكندرية و 6.5 و 5.57 حشرة فى محافظة البحيرة خلال موسمى الدراسة على الترتيب.
} 